\title{
"Dizer no todo": Palavra e imagem na obra de Mário Cesariny
}

\author{
MICHELE COUTINHO ROCHA
}

\section{Resumo}

O artigo tem como objetivo estudar a articulação entre a palavra e a imagem na obra de Mário Cesariny, presente em diversas práticas artísticas como poemas-poesia, picto-poemas, novelas-colagem e ainda em aquamotos e composições plásticas que integram referências linguísticas. Através da análise e compreensão da relação ou interação entre signos plásticos, icônicos e linguísticos, pretende-se identificar e caracterizar territórios de significação comum, feitos de apropriações mútuas, cruzamento e partilha de espaços e confluência de intenções. O estudo evidenciou relações de intertextualidade e interdiscursividade entre textos e imagens, discursos e conteúdos ideológicos.

Palavras-chave:

Mário Cesariny, Surrealismo Português, palavra/imagem 


\title{
"To say in all": Word an image in the work of Mário Cesariny
}

\author{
MICHELE COUTINHO ROCHA
}

\section{Abstract}

This article studies the relations between word and image in de work of Mário Cesariny, present in diverse artistic practices as poems-poetry, picto-poems, novels-collage and still in aquamotos and plastic compositions that integrate linguistic references. Through the analysis and understanding of the relations or interaction between plastic, iconic and linguistic signs, we intend to identify and characterize areas of common meaning, made of mutual appropriations, crossover and sharing spaces and confluence of intentions. The study showed relations of intertextuality

Keywords: and interdiscursivity between text and image, speeches and ideological contents. 


\title{
"Dince en todo": Palabra e imagen en la obra de Mário Cesariny
}

\author{
MICHELE COUTINHO ROCHA
}

\section{Resumen}

El artículo tiene como objetivo estudiar la articulación entre la palabra y la imagen en la obra de Mário Cesariny, presente en diversas prácticas artísticas como poemaspoesía, picto-poemas, novelas-collage y aún en aquamotos y composiciones plásticas que integran referencias lingüísticas. A través del análisis y comprensión de la relación o interacción entre signos plásticos, icónicos y lingüísticos, se pretende identificar y caracterizar territorios de significación común, hechos de apropiaciones mutuas, cruce y reparto de espacios y confluencia de intenciones. El estudio evidenció relaciones de intertextualidad e interdiscursividad entre textos e imágenes, discursos y contenidos ideológicos.

Palabras clave:

Mário Cesariny, Surrealismo Portugués, palabra/imagen 


\section{"Dizer no todo"}

O Surrealismo, à semelhança de outros movimentos literários e artísticos da Modernidade, persegue o sonho romântico de alcançar a "Obra absoluta", reflexo da convergência da multiplicidade de saberes num discurso único, potenciador do desenvolvimento do indivíduo e da sociedade. Na prática artística, o propósito surrealista traduz-se na convergência e integração das várias linguagens artísticas numa só.

A obra de Mário Cesariny, perfeitamente enquadrada nos propósitos do Surrealismo, revela igualmente a aspiração a um saber absoluto, materializado na procura de uma identidade poética assumida como expressão e realização integral do indivíduo, em que o poético e o plástico convergem para a concretização de um projeto global, potenciador de uma outra forma de pensar e de agir. O investigador e crítico Perfecto Cuadrado, no seu ensaio Palavra/ Imagem: Confluências, identifica na obra do autor "um projeto (realizado na medida do humano) de totalidade", no qual a diluição das fronteiras entre plástico e verbal integra um propósito abrangente de convergência e conciliação das polaridades, que corresponde ao "dizer no todo" (CUADRADO, 2004, p. 226, grifo do autor).

Estudar a obra de Cesariny, focando na interação entre o plástico e o verbal, passa necessariamente por perspetivar a obra do autor como um todo, convocando palavra e imagem para o mesmo plano interpretativo e compreensivo.

\section{Poemas-colagem: afirmação da visualidade poética}

No final da década de 1940, Cesariny realiza uma série de experiências que se inserem dentro da lógica do poema- 
-colagem, com fragmentos de frases e palavras recolhidos de jornais, reposicionados posteriormente sobre o papel por colagem, no sentido de adquirirem uma outra significação e valor visual.

Como refere Maria Jesús Ávila (2001), esta operação foi primeiramente ensaiada por Alexandre O'Neill em 1947, tendo o autor enviado uma carta a Mário Cesariny na qual ele explica, juntamente com um exemplo dessas experimentações, as vantagens do método na construção de um "novo sentido lógico" (ÁVILA, 2001, p. 287).

Estas experiências têm como fundamento a fórmula para a construção de um poema surrealista, defendida por André Breton no Primeiro Manifesto de 1924, baseada nas argumentações do poeta Tristan Tzara:

Os processos surrealistas exigiram aliás ser alargados. Tudo é bom para obter de certas associações a desejada instantaneidade. [...] Pode até intitular-se POEMA aquilo que se obtém pela reunião tão gratuita quanto possível (se quiserem, respeitamos a sintaxe) de títulos e de fragmentos de títulos recortados dos jornais (BRETON, 1993, p. 48).

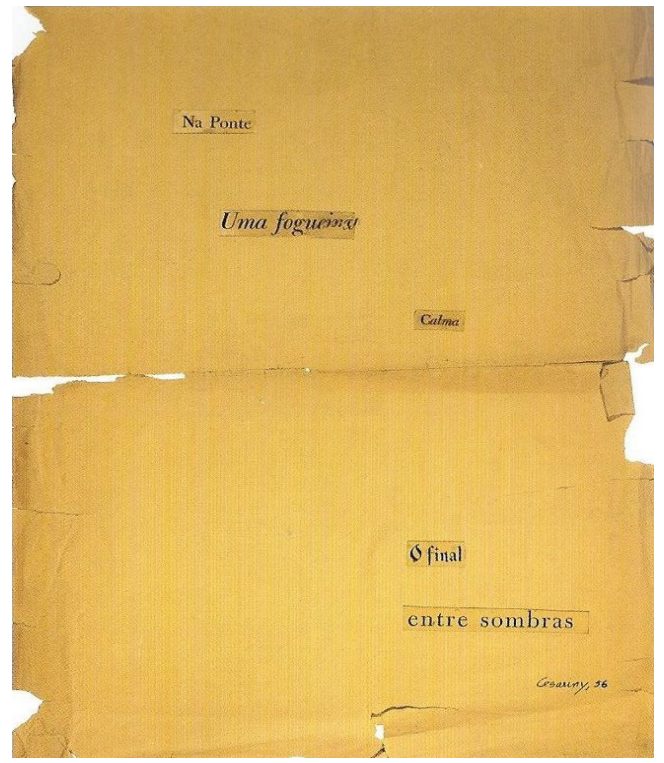

Contrariamente ao tipo de colagem proposto por Tzara, que consistia em recortar as palavras de um texto impresso,

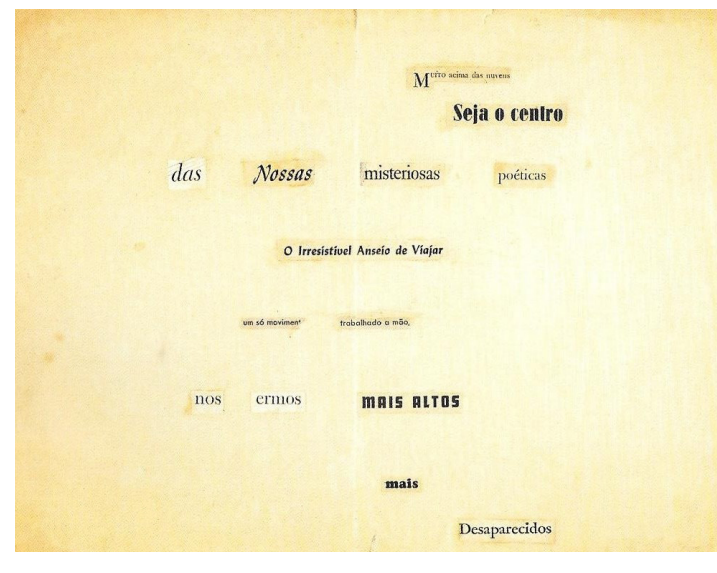

Figura 1. Mário Cesariny, Muito acima das nuvens, c. 1947-1949; colagem sobre papel, 21,7 $\times 29,6$ cm; col. Mário Cesariny, Lisboa.

Figura 2. Mário Cesariny, $\mathrm{Na}$ ponte, 1956; colagem sobre papel, $45 \times 34 \mathrm{~cm}$; col. F.C.M., V. N. Famalicão. 
Figura 3. Mário Cesariny, Poème (página esquerda), 1947; colagem sobre papel, $31,2 \times 23,9 \mathrm{~cm}$; col. C.A.M.J.A.P.

Figura 4. Mário Cesariny, Poème (página direita), 1947; colagem sobre papel, 31,2 X 23,9 cm; col. C.A.M.J.A.P. colocá-las num saco e reposicioná-las sobre o papel respeitando inteiramente a ordem de extração, Breton refere-se à necessidade de preservar a estrutura formal. Para Breton, a sintaxe deve ser mantida mesmo nas produções surrealistas mais experimentais. Perfecto Cuadrado defende a existência na colagem surrealista de em "acaso vigiado face ao acaso absoluto da colagem inventada por Tristan Tzara" (CUADRADO, 1998, p. 45, grifo do autor).

No mesmo sentido, nos poemas-colagem de Mário Cesariny, a seleção dos diferentes fragmentos e a posterior distribuição no espaço compositivo não é um processo inteiramente arbitrário. $\mathrm{O}$ poema-colagem Muito acima das nuvens (Figura 1) mostra como os diferentes fragmentos de frases e palavras são associados em segmentos sintáticos, combinados entre si por ligações gramaticais que asseguram a coerência sintática, mantendo, no entanto, a ambiguidade semântica, favorecendo a livre associação ou dissociação das ideias: "Muito acima das nuvens/ Seja o centro/ das Nossas misteriosas poéticas/ O irresistível Anseio de viajar/ um só movimento/ trabalhando a mão/ nos ermos mais altos".
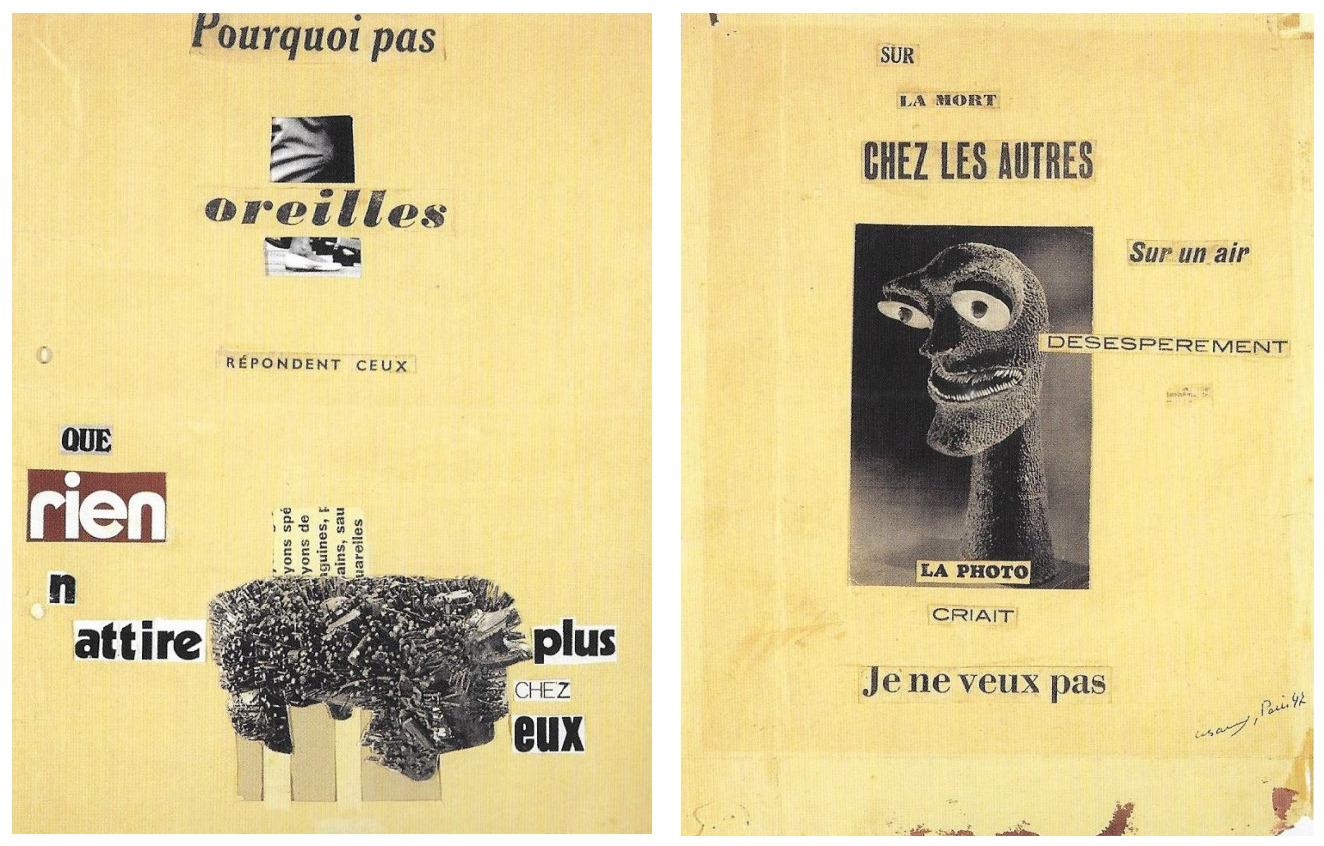

A distribuição espacial dos diferentes fragmentos, com espaçamento entre linhas, tipos e tamanhos de letra distintos, 
confere ao poema visualidade plástica. $\mathrm{O}$ destaque de partes do texto condiciona o olhar e cria hierarquias na leitura. Nesse sentido, o poema, apesar de manter a estruturação linear da escrita, é aprendido no imediato como signo visual mais do que unidade linguística.

Em poemas-colagem, tais como Na Ponte, de 1956 (Figura 2), os elos sintáticos são suprimidos e os fragmentos organizados em sequências breves são simplesmente justapostos, à semelhança das construções paratáticas.

Noutros poemas-colagem, Cesariny associa fragmentos de frases e palavras a imagens recolhidas de jornais e revistas. O díptico Poèmes, constituído por dois poemas-colagem, denota abordagens distintas no que concerne à relação entre palavra e imagem.

Em Sur la mort (Sobre a morte) (Figura 3), os fragmentos de frases e palavras são articulados com uma imagem em preto e branco, de recorte geométrico, posicionada no centro da mancha de texto. A estrutura compositiva, relativamente simples, aproxima-se da composição tipográfica característica dos jornais, com os títulos centrados ou alinhados à imagem ou ainda sobrepostos de forma ordenada, de modo a não comprometer a legibilidade da figura.

Cesariny opta por uma estratégia de complementaridade ou equivalência entre palavra e imagem, tal como é descrita por Molitor (apud SANTAELLA \& NÖTH, 2008). A imagem enfatiza o significado das palavras, e as palavras explicitam o conteúdo da imagem. A representação de um rosto insólito, algo inquietante e perturbador, encontra coerência semântica no texto, sobretudo nas referências "La mort" (A morte), "Desespérement" (Desesperadamente) ou na sequência sintática La photo/ criait/ jene veux pas (A foto/ gritava/ eu não quero), por sua vez as palavras fornecem uma explicação da imagem reduzindo a sua polissemia. É ainda de salientar a convergência entre signo visual e signo fonético, implícita na referência "La photo" sobreposta à imagem fotográfica.

O poema-colagem Pourquoi pas (Porque não) (Figura 4) apresenta uma estrutura mais complexa, não só pelo aumento da subjetividade semântica, mas também da abstração visual, fatores que favorecem a livre associação de ideias. Os recortes de frases e palavras são recontextualizados em três sequências, posicionadas sobre a linha central e nas laterais, com coerência sintática e consistência semântica, quando consideradas de forma isolada. Porém, a leitura conjunta do poema, 
apesar de garantir a coerência sintática através de ligações gramaticais, instaura a rutura ao nível semântico, abrindo o texto à possibilidade de múltiplas significações.

Acresce ainda a relação com a imagem, iminentemente abstrata, que intensifica a ambiguidade ao nível da significação. Os recortes de imagens, posicionadas sobre a linha central, assumem um caráter tendencialmente abstrato, à exceção de um pequeno recorte onde é visível a representação de um pé. Uma das imagens, de recorte irregular, integra uma mancha de texto sem consistência linguística, que assume um caráter puramente visual.
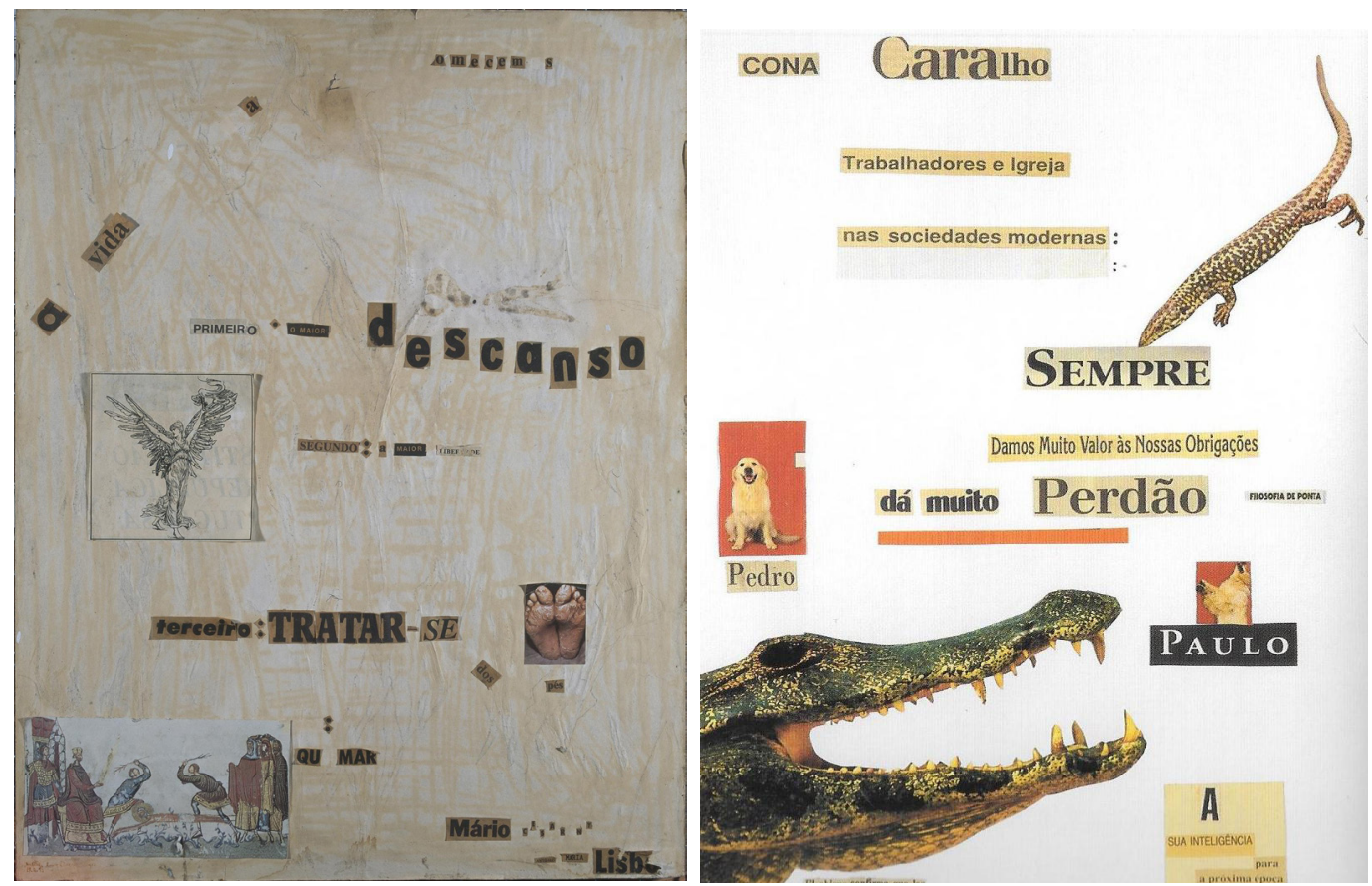

Figura 5. Mário Cesariny, A Vida, Poème, n. dat., colagem sobre papel, 31,2 x 23,9 cm; col. F.C.M., V. N. Famalicão.

Figura 6. Mário Cesariny, Abril, Semana Santa, 1998; colagem sobre papel, $40 \times 28 \mathrm{~cm}$; col. F.C.M., V. N. Famalicão.
Em um poema-colagem intitulado A Vida (Figura 5), que já não se encontra em sua integralidade, o autor associa às imagens e aos fragmentos de palavras, letras recortadas, posteriormente reposicionadas com uma determinada orientação espacial. O poema, acompanhado de imagens insólitas, propõe uma reflexão sobre as ideias essenciais da vida e termina com a assinatura de Mário Cesariny, juntamente com a referência ao nome do surrealista António Ma- 
ria Lisboa, de forma não convencional com recurso a recortes de palavras e letras.

A prática do poema-colagem persiste ao longo da obra de Mário Cesariny. Numa composição mais recente intitulada Abril, Semana Santa (Figura 6), os recortes de imagens, frases e palavras, reposicionados com alguma ambiguidade semântica, integram um discurso contestatário e subversivo, que tem como alvo principal a igreja católica. De forma irónica, os representantes eclesiásticos e as personagens bíblicas são associados a imagens de répteis e outros animais. Esse discurso encontra continuidade na poética de Cesariny. Em Políptica de Maria Klopas, dita Mãe dos Homens (CESARINY, 2005) - denominada pelo autor como "[...] história dadá de Nossa Senhora das Dores" (CESARINY, 1997, p. 51) -, Cesariny expõe de uma forma negativa e destruidora o mito da Nossa Senhora. A Virgem Maria, que colocou o seu corpo à disposição dos desígnios de Deus, é apresentada como uma vítima passiva da vontade divina: "Àquela/ que em vida/ foi desapossada/ foi morta/ descida/ crucificada/ e ao terceiro dia/ não foi nada [...]" (CESARINY, 2005, p. 24).

\section{Picto-poesia: diálogos intertextuais e inter- discursivos}

Durante a sua estadia em Paris, entre agosto e outubro de 1947, Mário Cesariny realiza um conjunto de experiências picto-poéticas (Figuras 7, 8 e 9), em que associa o recorte de palavras e imagens à intervenção plástica. A técnica, inventada por Victor Brauner, pretende ultrapassar a limitação dos sistemas significantes e a separação dos géneros (verbal e visual), ao integrar numa mesma unidade significativa palavra e imagem pictórica. Nesses trabalhos, Cesariny incorpora elementos pictóricos, recortes de imagens, excertos de frases e de palavras, fragmentos de papel com padrões estampados e ainda objetos, em superfícies intervencionadas com aguadas, gotejamentos e tintas sopradas.

Nas experiências picto-poéticas, assim como em outras posteriores que ele desenvolverá ao longo da sua obra, Cesariny estabelece relações de intertextualidade ${ }^{1}$ e interdiscursividade $^{2}$ com a sua obra e a de outros autores. Assim, nestes trabalhos Cesariny incorpora representações que derivam de outras obras suas, bem como discursos temáticos e figurativos que evocam a obra de André Breton e principalmente a de Victor Brauner. 
no texto. Cesariny estabelece uma relação intertextual com a sua própria obra. Essa personagem surge igualmente em uma outra representação sensivelmente da mesma data, intitulada Homenagem a Victor Brauner. Cesariny mostra profunda admiração pela obra de Victor Brauner, com quem conviveu em Paris em 1947.

No mesmo sentido, os picto-poemas constituem uma homenagem ao pensamento e à obra deste autor, patente não só na representação da personagem com olhos em forma de espiral, mas também no conteúdo linguístico. Cesariny estabelece uma relação interdiscursiva com a obra de Victor Brauner, com alusão a discursos temáticos e figurativos centrados na problemática do olho e do olhar, recorrentes na obra do autor.

É amplamente conhecida a importância do olho e sobretudo do olhar, entendido como expressão mística, na obra de Victor Brauner. $\mathrm{O}$ autor representou o olho de forma quase obsessiva ao longo da sua obra. $\mathrm{O}$ famoso autorretrato intitulado Enucleated Eye, de 1931, é entendido por muitos como uma premonição da perda do olho esquerdo que o autor acabaria por sofrer em 1938. Brauner e os outros surrealistas viram neste acontecimento a confirmação do pintor vidente, assim como das teorias do acaso objectivo, da omnipotência do sonho e da imaginação. Após este acontecimento, a obra de Victor Brauner torna-se profundamente introspectiva e mística, refletindo um interesse crescente pelo oculto, a magia e a alquimia. Intensifica-se a ideia do olho como centro místico e canal privilegiado para o conhecimento. No mesmo sentido, nos picto-poemas de Cesariny os olhos em forma de espiral materializam o olhar entendido como visão interior. Um olhar que extravasa a percepção objetiva da realidade exterior para se centrar na projeção mental do subjetivo, com recurso ao sonho, à imaginação e à memória.

O conteúdo subjacente às personagens encontra coerência semântica ao nível linguístico. As sequências sintáticas "Sources de/ L'ILLUSION/ la vertu/ L'oeil" (Fontes de/ ILU$\mathrm{SÃO/virtude/} \mathrm{o} \mathrm{olho)} \mathrm{e} \mathrm{"La} \mathrm{voie/} \mathrm{sauvage/} \mathrm{DES} \mathrm{SONGES"} \mathrm{(O}$ caminho/ selvagem/ DOS SONHOS), inseridas em continuidade da imagem pictórica, reforçam a noção de olhar interior como caminho privilegiado para o sonho e o imaginário. De certa forma, Cesariny evoca a conhecida frase de Breton "L'œil existe à l'état sauvage" (O olho existe em estado selvagem). A frase que abre o livro Surréalisme et la Peinture (1928) (Surrealismo e a Pintura) faz apologia do olhar livre de todos os condicionalismos, à mercê do imaginário, instrumento de re- 
velação e libertação, que restitui ao homem a consciência de todas as suas capacidades.

Do mesmo modo, noutro picto-poema, a frase "Voir deux fois" (Ver duas vezes), acompanhada pela imagem de um esqueleto, deixa implícita a ideia de um olhar que ultrapassa a visão superficial da realidade cotidiana para penetrar profundamente no ser - à semelhança de uma imagem radiográfica - , e revelar as realidades ocultas.
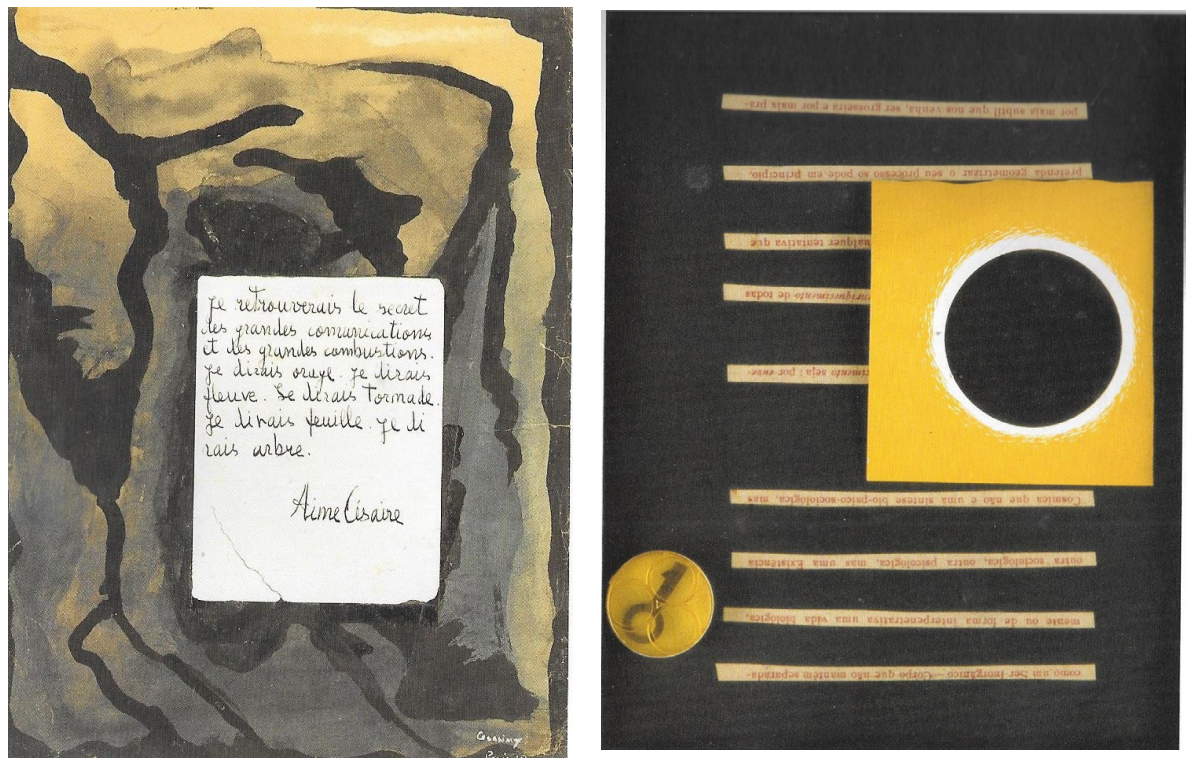

Figura 10. Mário Cesariny, A máquina de atravessar qualquer tempo, 1947; tinta-da-china, aguada e colagem papel, $32 \times 23,6 \mathrm{~cm}$; col. Mário Cesariny, Lisboa.

Figura 11. Mário Cesariny, Como um ser inorgânico, 1956; objecto e colagem sobre madeira, 24,5 × 19,5 $\mathrm{cm}$; col. particular.
Ainda em 1947, e neste contexto de obras evocativas de outros autores, Cesariny realiza uma série de pinturas intituladas $A$ máquina de atravessar qualquer tempo, em que presta homenagem a Aimé Cesaire, poeta amplamente celebrado pelos surrealistas.

A obra que inicia a série insere-se dentro da lógica do picto-poema, com uma convergência entre palavra poética e imagem pictórica (Figura 10). Numa superfície intervencionada plasticamente com manchas informais de tinta opaca sobre aguada, Cesariny incorpora um excerto manuscrito do poema de Aimé Cesaire, Cahier d'un retour au pays natal (Caderno de retorno para o país natal), publicado nesse ano: "Je retrouverais le secret des grandes communications et des grandes combustions. Je dirais orage. Je dirais fleuve. Je dirais tornade. Je dirais feuille. Je dirais arbre"3. 
À semelhança dos picto-poemas anteriores, o discurso poético encontra corência semântica ao nível visual. O caráter informal da imagem pictórica, com a sugestão de um espaço dinâmico que converge para o centro, marcado pelo contraste e luminosidade, presta-se à visualidade implícita no poema.

O poema Cahier d'un retour au pays natal evoca o retorno à paisagem da Martinica, terra natal do poeta, como metáfora da recuperação de uma identidade perdida, entendida como um espaço-tempo ideal anterior à alienação. O excerto do poema manuscrito expressa o desejo de união com a natureza na sua totalidade, entendido como concordância perfeita entre o mundo interior e o exterior, materializado na busca por um sentido de identidade, o "Negre essentiel", a África e os seus valores, através da supressão das imposições sociais e culturais. A paisagem corrompida pelo colonizador torna-se a paisagem restaurada.

Cesariny estabelece uma relação entre a imagem pictórica, o poema e o título. A representação, à semelhança do poema, expressa o entendimento da paisagem como corpo originário e primitivo no limiar do mundo simbólico e conceptual, num plano em que não existe separação ou diferença entre o sensível e o inteligível, onde tudo é corpo sensível, aroma, som, ritmo. As formas, tendencialmente abstratas, resultantes da dinâmica gestual, procuram captar a forma na sua essência. A atitude de simplificação e redução formal evoca o retorno a uma linguagem pré-formal, a recuperação de um pensamento originário ou primitivo que busca o sentido de totalidade, implícita no título A máquina de atravessar qualquer tempo.

No mesmo sentido, um outro picto-poema intitulado Como um Ser Inorgânico (Figura 11), dedicado a António Maria Lisboa - um dos principais teóricos do Surrealismo português - integra numa mesma unidade compositiva e significativa, excertos do texto Operação do Sol, de António Maria Lisboa, assim como elementos visuais que evocam no seu conjunto a reintegração do ser, expandido na sua totalidade, numa unidade cósmica.

A obra carateriza-se pela clareza cromática e simplificação da execução, sem recurso a valores matéricos ou texturais, mas também pela redução formal dos elementos compositivos, numa aproximação às palavras de António Maria Lisboa, em uma composição em que prevalece o elemento visual. O excerto do texto de António Maria lisboa, recortado e transposto de forma linear num bloco de texto, é aprendido de imediato como signo visual não só pelo aumento do espaçamento entre linhas, determinan- 
te numa certa cadência visual, mas também pela sobreposição de um dos elementos visuais que interrompe o discurso.

No texto Operação do Sol, que se encontra na base da conceção da obra, António Maria Lisboa descreve a aventura ou a experiência do encontro, conducente à transformação e enriquecimento do indivíduo. $\mathrm{O}$ autor defende a necessidade de uma outra linguagem, uma manifestação profunda do Corpo que vá para além dos sentidos, que proporcione ao indivíduo a experiência da Unidade, um conhecimento de si próprio e do ritmo universal. A poesia, a "Negra Actividade Poética", possibilitará ao indivíduo estabelecer uma ligação com o Cosmos, por meio de "um movimento incessante de enriquecimento comum". Ao realizar a Unidade, o Homem pode finalmente afirmar-se como "Ser Inorgânico - Corpo" enquanto "Existência Cósmica". Neste sentido, António Maria Lisboa propõe o Amor como força convergente, o "caminho dissolvente" para a reconstituição do corpo uno e a fusão com o Universo (LISBOA, 2005).

Mário Cesariny aproxima a ideia do "Ser Inorgânico", integrado em toda a sua extensão e pluralidade numa "Existência Cósmica”, à imagem do círculo ou da esfera. António Maria Lisboa, em uma carta endereçada a Mário Cesariny, na qual ele clarifica a sua posição relativamente à Metaciência, recorre à imagem da esfera para ilustrar a posição do poeta ou do Mago - detentores de todos os poderes e capacidades - no meio do "Centro da Esfera do Universo". O autor reforça: "A Metaciência pretende entre outras coisas dar ao homem, ao Poeta a sua posição no Centro da Esfera deste Universo, que o mesmo é dizer fazer que o Poeta possua no seu cérebro todos os raios da esfera deste universo" (LISBOA, 2005, p. 196-197). Ao conquistar o autoconhecimento, o Homem expande-se no Universo e o Universo unifica-se no Homem "pois este é a projeção do Homem e o Homem a Concreção do Universo a um Ponto" (LISBOA, 2005, p. 196-197).

Ao evitar a simetria e a centralidade, Mário Cesariny confere tensão e dinamismo à composição (Figura11), como metáfora de um caminho a percorrer e de um objetivo a alcançar. A chave colocada num invólucro transparente, na parte superior do plano, simboliza a ação a empreender no sentido de restituir ao Homem o seu lugar no "Centro da Esfera do Universo". Nas palavras de António Maria Lisboa: "Seja-me permitido, uma vez por todas, apontar a Grande Legenda que encerra a Chave da ação deste universo" (LISBOA, 2005, p. 30). 
A relação intratextual e interdiscursiva com o pensamento de António Maria Lisboa é visível em outras obras que articulam igualmente o plástico e o verbal. Numa composição mais recente de natureza autobiográfica, Este é o meu testamento de Poeta (Figura 12), Cesariny associa a figura feminina de corpo triangular, recorrente na obra do autor, e entendida como afirmação da sua identidade poética, às palavras de António Maria Lisboa. O poema, integrado na imagem pictórica (Figura 12), exalta o pensamento poético como linguagem subversiva e transformadora: "a poesia! a poesia!/ e não este lamento/ esta linha de nojo que frustra a Voz/ [...]."

Em sintonia com o pensamento de António Maria Lisboa, Cesariny aproxima a identidade do poeta, implícita nessas representações, ao mago da tradição alquímica, detentor de todos os poderes e capacidades, impulsionador da ação e da transformação. A varinha nas mãos da figura, símbolo do poder das artes mágicas, simboliza a capacidade de realização do Poeta, capaz de transmutar a realidade, agindo no sentido do seu próprio enriquecimento. Cesariny, num desenho (Figura 13) dedicado a António Maria Lisboa, que reúne a palavra e os elementos gráficos da imagética do autor, refere-se mais uma vez a António Maria Lisboa como a "Voz".
Figura 12. Mário Cesariny, Este é o meu testamento de Poeta, 1994; acrílico sobre serigrafia, $65 \times 48,5$ $\mathrm{cm}$; col. particular.

Figura 13. Mário Cesariny, Voz de António Maria Lisboa, n. d; tinta-da-china sobre papel; col. particular.
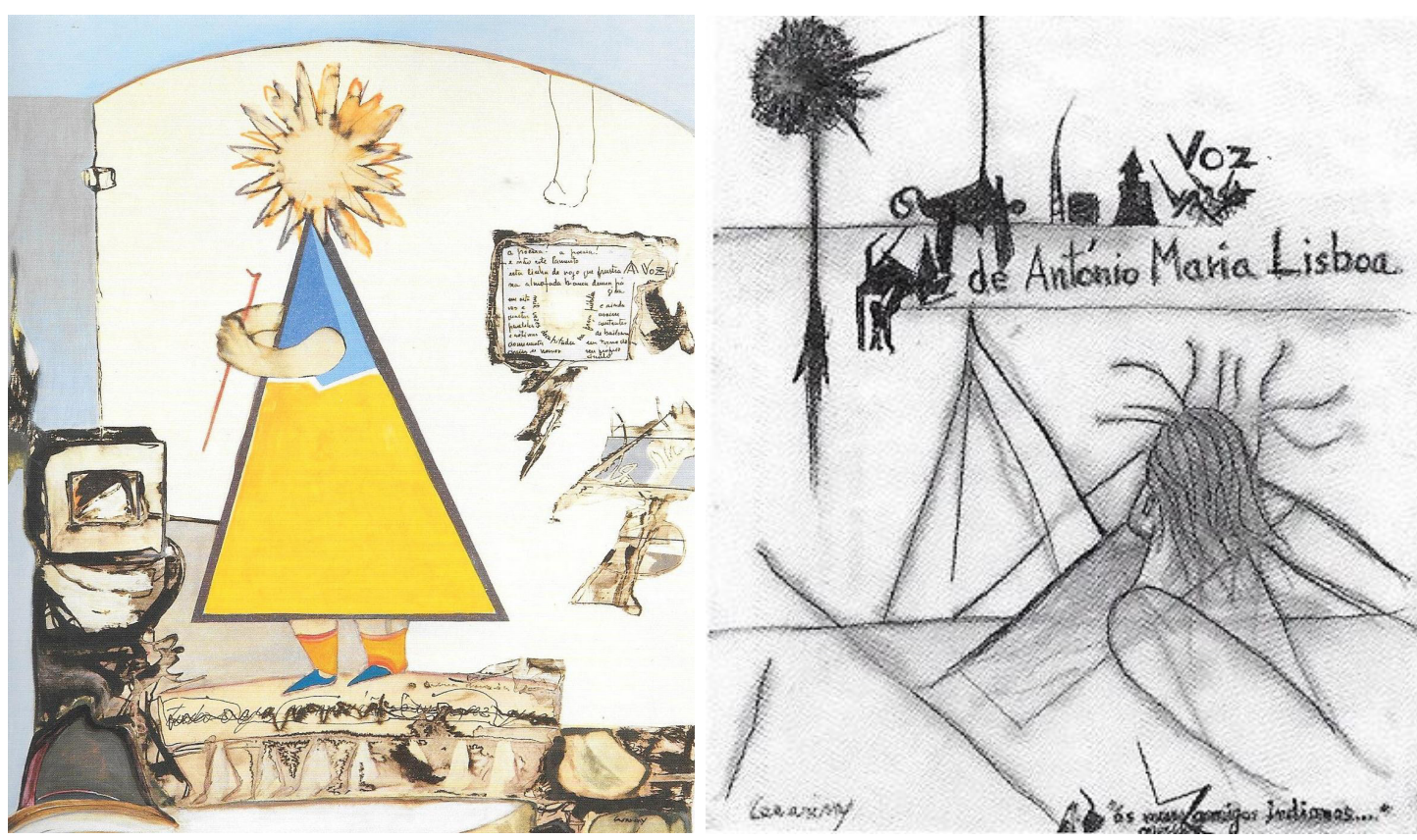
menagem a Erik Satie (Figura 16), Cesariny inscreve numa partitura musical com símbolos gráficos e termos linguísticos próprios, recortes de imagens - alguns com legenda - que recriam o imaginário do final do século XIX (representações de animais, instrumentos musicais, peças de mobiliário, figuras humanas, entre outras), numa alusão humorística às caraterísticas particulares da obra de Erik Satie.
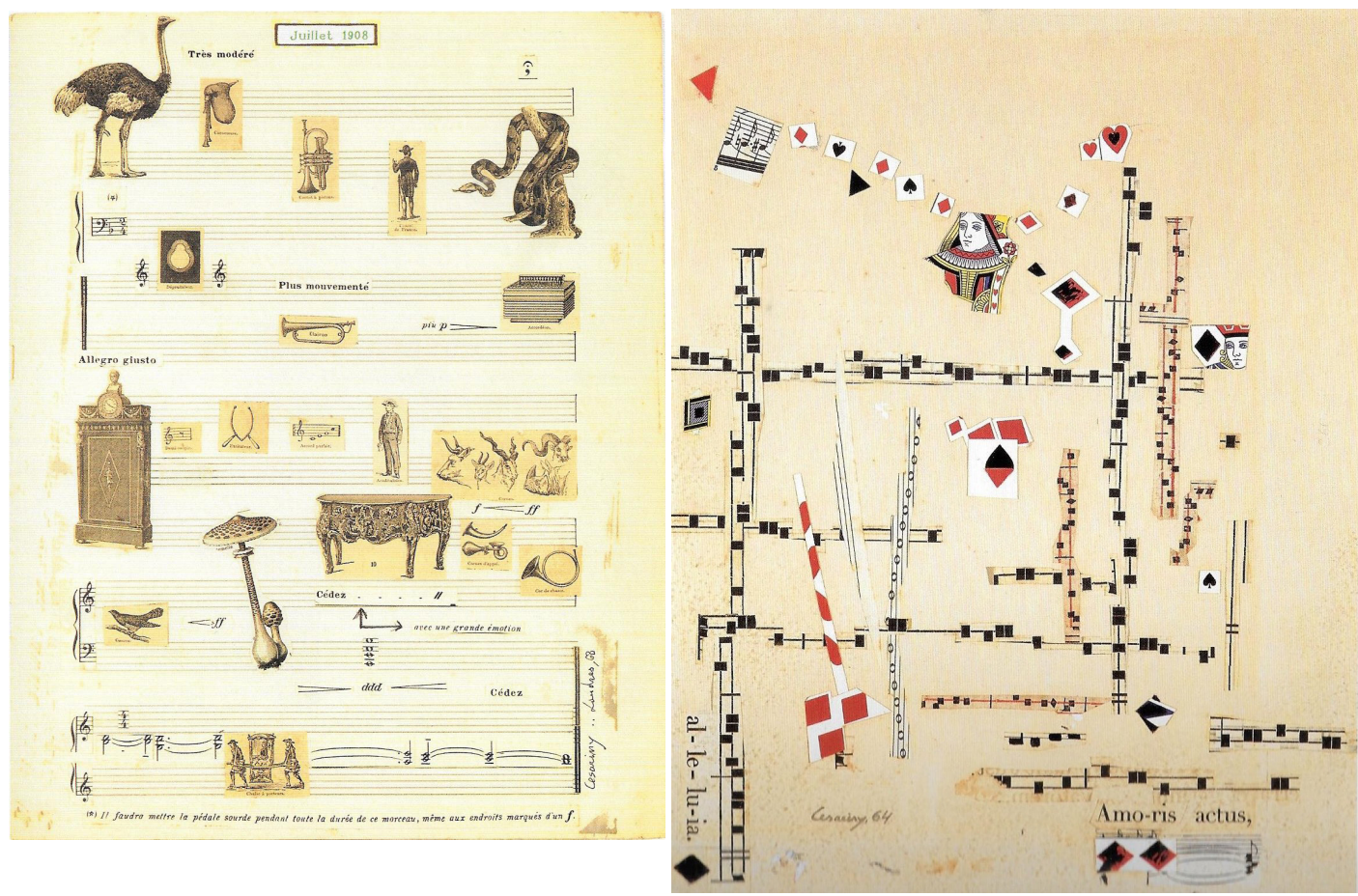

Erik Satie, conhecido compositor francês, teve um papel relevante na vanguarda parisiense no começo do século XX. Foi o criador da furniture music, a conhecida música de ambiente, gênero musical que pretende criar uma paisagem sonora, uma ambientação que favoreça a libertação total dos sentidos. Apologista da convergência entre várias linguagens artísticas, estabeleceu ligação com os movimentos Dadaísmo e Surrealismo. Guillaume Apollinaire utilizou pela primeira vez o termo "surrealista" para caracterizar a sua música, pela proximidade com o mundo dos sonhos e do inconsciente.

Cesariny estabelece uma relação interdiscursiva com a

Figura 16. Mário Cesariny, Homenagem a Erik Satie, 1968; colagem sobre papel; $31 \times 24,5$ cm, col. F.C.M., V. N. Famalicão.

Figura 17. Mário Cesariny, al-le-lu-ia, Amo-ris actus , 1964; colagem sobre papel; $35,5 \times 27,5$ cm, F.C.M., V. N. Famalicão. 
obra de Erik Satie. A colagem de imagens insólitas sobre a pauta musical, segundo uma dinâmica e lógica própria que simula a composição musical, evoca o caráter multifacetado da obra de Erik Satie, nomeadamente o uso inusitado de escalas musicais com recurso a objetos do cotidiano para produzir sons que possibilitassem a libertação dos sentidos, bem como o recurso a procedimentos harmônicos quase aleatórios, com justaposição de elementos heterogêneos, sem desenvolvimento lógico de causa e efeito.

Numa obra anterior, intitulada al-le-lu-ia, Amo-ris actus de 1964 (Figura 17), Mário Cesariny cria a ilusão de uma partitura musical, através da colagem de fragmentos de pautas de música e cartas de jogar, dispostos em sequências visuais que simulam o ritmo da composição musical. Cesariny associa à linguagem musical o tema da prestidigitação e do ilusionismo, numa alusão interdiscursiva à obra do artista Joan Brossa, um dos criadores mais importantes da vanguarda catalã. A sua obra, complexa pela densidade e diversidade de manifestações, expressa o entendimento da poesia como um conceito abrangente, que supera as fronteiras entre gêneros e disciplinas literárias e artísticas, para onde confluem múltiplas formas de expressão como a poesia, o teatro, o cinema, a poesia visual, os objetos, as instalações, entre outras.

A linguagem subtil e enigmática da magia, da prestidigitação e do ilusionismo são estruturantes no imaginário poético de Joan Brossa. O jogo, o enigma e o azar constituem, segundo o poeta, os elementos essenciais do indivíduo e da atividade criativa. Em toda a sua obra, os jogos de mãos com naipres ou dados, transfigurados em jogos de linguagem, convertem-se numa arma eficaz das transgressões formais e significativas do poeta (GUERRERO, 2001). No mesmo sentido, na obra de Cesariny, o simulacro da composição musical subverte e transforma a representação gráfica da notação musical em representação plástica da melodia e do ritmo musical para celebrar o encontro e a união amorosa entre a dama e o valete.

\section{Aquamotos: entre o automatismo e a intencio- nalidade significante}

Em 1976, Cesariny realiza um conjunto de aquamotos (Figuras 18,19 e 20) onde associa às imagens geradas pelo acaso e por processos de automatismo, frases manuscritas reveladoras de conteúdo semântico. As frases Aos dois deo o ramo, 
O Mar o deo aos dois ou As mãos na água a cabeça no mar integradas nas imagens geradas pelo efeito espontâneo da água, conferem às composições coerência semântica, sobretudo pela ligação entre a significação marinha - reforçada pela alternância cadenciada dos sons - e a técnica do aquamoto.
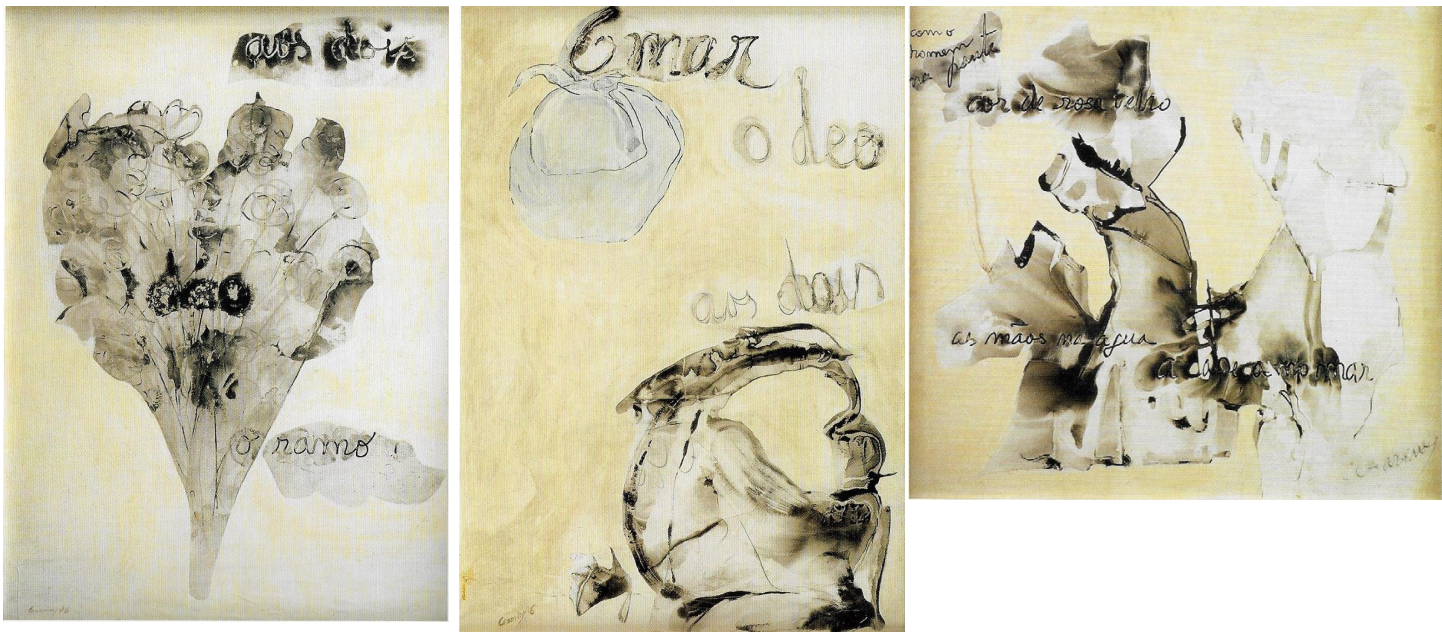

O Aquamoto, técnica inventada pelo autor, utiliza os efeitos espontâneos da água para aceder a novas imagens. O desenho inicial, abstrato ou figurativo, é alterado de uma forma radical através da aplicação de água. $\mathrm{O}$ poder transformador da água dissolve o desenho prévio e possibilita a descoberta de outras imagens. Essa ideia está implícita no conceito de "des-pintura" que o autor utiliza para designar a sua ação criativa. Na obra plástica de Mário Cesariny, "as tensões nos elementos constituintes da imagem conduzem-nos a jogos de de-composição das formas por continuidade e separação, de acumulação-rerefação das matérias por empastamento e colagem ou por raspagem e laceração, de obscurecimentos e exaltação de cromatismos" (PINHARANDA, 2004, p. 21). O processo criativo é entendido como ato de dissolvência e destruição que possibilita a construção ou emergência de uma outra realidade. Nesses aquamotos, o efeito espontâneo da água, assumida como força criativa impulsionadora de novas imagens, encontra expressão e continuidade nas sequências sintáticas, em que a simbologia marinha é entendida como dimensão reveladora e força convergente.
Figura 18. Mário Cesariny, Aos dois deo o ramo, 1976; aquamoto e têmpera sobre papel colado em tela, $70 \times 50 \mathrm{~cm}$; col. particular.

Figura 19. Mário Cesariny, O Mar o deo aos dois, 1976; aquamoto e têmpera sobre papel colado em tela, 70 x $50 \mathrm{~cm}$; col. particular.

Figura 20. Mário Cesariny, As mãos na água a cabeça no mar,

n. dat.; aquamoto e têmpera sobre papel colado em tela, $49 x$ $55 \mathrm{~cm}$; col. particular. 
Na imagética de Mário Cesariny, o mar constitui o elemento transformador que conduz à dissolvência da realidade, à sua desmaterialização, para concretizar uma outra forma de realização, conducente à libertação e superação do indivíduo. No poema Barricada, que integra o livro Pena Capital, a água sob a forma de dilúvio, metáfora da exaltação dos inconformados "belos espontâneos e livres", traz a destruição e com ela a possibilidade de transformação e regeneração. O poder destrutivo da água revela uma outra consciência e institui uma nova era: "E quando essa água morna inundar tudo, então, ó arquitectos, trabalhai de novo [...]" (CESARINY, 2005, p. 29). $\mathrm{O}$ mar é igualmente o território propício ao encontro e união com o outro. Em Corpo Visível, a descoberta e a conquista do corpo amado, "maravilha longínqua obscura inexpugnável rodeada de água" é a grande viagem marítima dos corsários ao "país dos amantes" (CESARINY, 2005, p. 67). Em inúmeros poemas o mar transfigura-se no corpo amado: "Dir-te-ei que os meus dias foram os teus dias o meu leito o teu corpo este mar" (CESARINY, 2005, p. 75).

Para Mário Cesariny o mar, evocado nas obras poéticas e plásticas, é o elemento transformador e libertador que dissolve e incorpora o ser, reintegrando-o numa dimensão una. Nesse sentido, ela é a metáfora perfeita para o amor, concretizado no encontro e na união com o outro, na medida em que ela restitui um sentimento perdido de unidade e integridade corporal, presente nas frases Aos dois deo o ramo ou $\mathrm{O}$ Mar o deo aos dois. A alternância cadenciada dos sons das vogais e consoantes, repetidos em intervalos regulares, bem como a alteração de uma das vogais, sugere o ritmo do movimento das marés.

Assim, as imagens resultantes do efeito espontâneo da água encontram continuidade semântica na simbologia marinha sugerida nas frases manuscritas. O aquamoto, entendido como processo criativo de destruição e de construção de uma outra realidade, aproxima-se da simbologia marinha. Por sua vez, o mar, entendido como elemento dissolvente e reconstituinte, é igualmente uma metáfora do processo criativo.

\section{Variações da novela-colagem: Timothy McVeigh - O condenado à morte}

Há ainda a salientar as experiências próximas da novela-colagem, sendo que o livro Timothy McVeigh - O condenado à mortes, constitui o melhor exemplo. O livro publicado 
em 2006, poucos meses antes da morte de Cesariny, constitui uma declaração pública do autor contra a pena de morte, sendo especialmente dirigido ao povo americano. Mais do que preocupações estéticas ou literárias, a obra tem a pretensão de suscitar no observador uma consciência crítica que possibilite uma reflexão profunda sobre a crueldade e desumanidade da pena de morte.

A obra constitui uma interpretação muito pessoal dos acontecimentos que envolveram a condenação e execução de Timothy McVeigh (1968-2001), um ex-soldado americano responsável pelo atentado em Oklahoma em 1995, que provocou um número considerável de mortes. Timothy McVeigh justificaria a sua violência como retaliação contra a tirania do governo totalitário do seu país. Após um julgamento mediático, Timothy McVeigh foi condenado à pena de morte por injeção letal e executado em 11 de Junho de 2001, sem mostrar qualquer arrependimento pelos seus atos.

O livro aproxima-se em alguns aspectos da tradição da novela-colagem. Desde logo, pela apropriação e manipulação de materiais diversos, provenientes de fontes distintas, imagens fotográficas, excertos de notícias, palavras, frases e títulos, recolhidos da imprensa e ainda de poemas impressos, posicionados sobre a imagem pictórica por colagem e posteriormente intervencionados. Cesariny inclui ainda a citação de excertos poéticos integrados na imagem pictórica. Um outro aspecto importante consiste na integração do plástico e do verbal em uma unidade significativa comum, segundo uma lógica narrativa. Através da convergência entre palavra poética e informativa, imagem pictórica e fotográfica, Cesariny cria uma disposição sequencial de imagens para traduzir uma sucessão de acontecimentos identificados no tempo e no espaço, de forma a suscitar uma reação do observador. Por fim, precisa-se destacar o caráter contestatário e subversivo da mensagem, assumida como denúncia à violação dos direitos humanos por parte dos EUA.

No entanto, subsistem algumas divergências importantes em relação às novelas-colagem tradicionais. Na conhecida novela colagem La femme 100 têtes (1929), Max Ernst parte das gravuras-folhetins do final do século XIX e integra-as num novo contexto, através de processos de displacement e assemblage (descolamento e montagem), que rompem com os códigos da mimeses e da coerência, conferindo-lhes uma nova configuração e um novo significado (ADAMOWICS, 1998). Nesse sentido, embora com um outro procedimento, 
Alexandre O'Neill, na realização da novela-colagem Ampola Miraculosa $a^{6}$ parte das gravuras de vários manuais de divulgação científica e, sem as manipular, atribui-lhes um outro significado através da introdução de uma legenda e de uma determinada disposição sequencial, que operam uma desconstrução da linguagem e do simbólico (Figura 21).
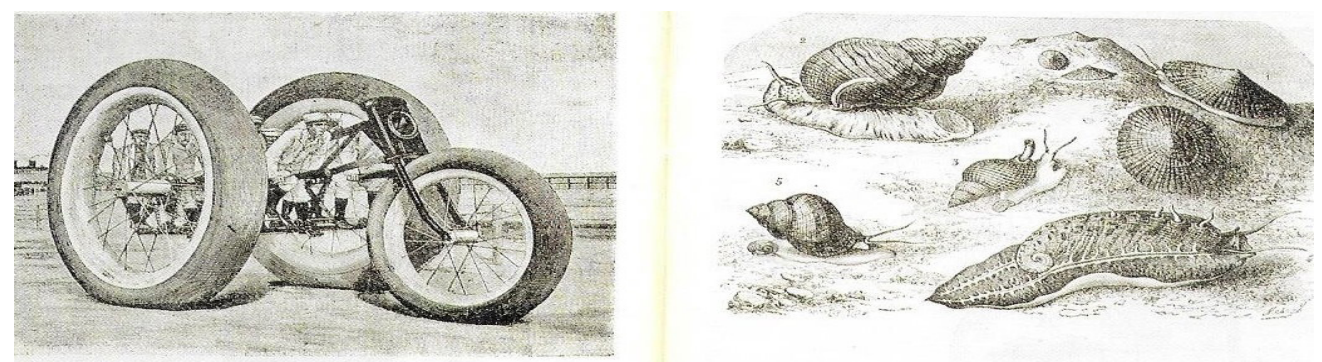

Figura 21. Alexandre O'Neill, A ampola miraculosa, 1949; novela-colagem, $21 \times 14,2 \mathrm{~cm}$; col. particular, Lisboa.
No livro de Cesariny, a apropriação e a integração de mensagens icónicas e verbais preexistentes no espaço pictórico, operam segundo uma lógica de continuidade que não perturba a coerência do discurso. As imagens fotográficas, títulos e excertos de notícias recolhidos da imprensa e ainda os poemas impressos e as citações poéticas, confrontados com a imagem pictórica, contextualizam o discurso no espaço e no tempo, reforçando a coerência da disposição sequencial das imagens e do discurso narrativo.

Mário Cesariny interpreta um conjunto de acontecimentos reais, identificados no espaço e no tempo, segundo uma dinâmica de sucessividade que parte do anúncio da morte do condenado para recuar depois no tempo e reposicionar a ação no julgamento e condenação de McVeigh. Segue-se a representação pormenorizada da execução, tal como é descrita pela imprensa. No final, Cesariny faz o elogio fúnebre do condenado, estabelecendo uma relação 
intertextual com os poetas William Ernest Henley, Oscar Wilde e Teixeira de Pascoais.

Na primeira representação (Figura 22) que serve de capa ao livro, Mário Cesariny define um espaço fechado, delimitado por uma moldura texturada com incisões lineares, realizadas sobre tinta espessa. A densidade matérica e formal em contraste com o espaço interior adjacente, tendencialmente vazio à exceção da colagem de um recorte com a palavra "hoje", acentua a perspectiva da existência de um plano separador entre o observador e o espaço onde decorre a ação. Cesariny aproxima a imagem de um palco de teatro onde a representação é levada à cena, dentro do qual o observador é intimado a entrar no contexto da cena figurada. No centro, a colocação de uma estrutura retangular amovível densamente texturada, suspensa na aresta superior, juntamente com o recorte da palavra "hoje", concentra o olhar do observador e interrompe a narrativa.

Ao suspender a ação, Cesariny convoca o observador a tomar a decisão de levantar a estrutura amovível e a dar continuidade à narrativa, de uma forma consciente e voluntária, tornando-se também ele numa testemunha da execução. Dessa forma, Cesariny intima o observador a testemunhar a execução de Thimothy McVeigh, a refletir sobre a situação, no sentido de construir uma perspectiva crítica relativamente à pena de morte.
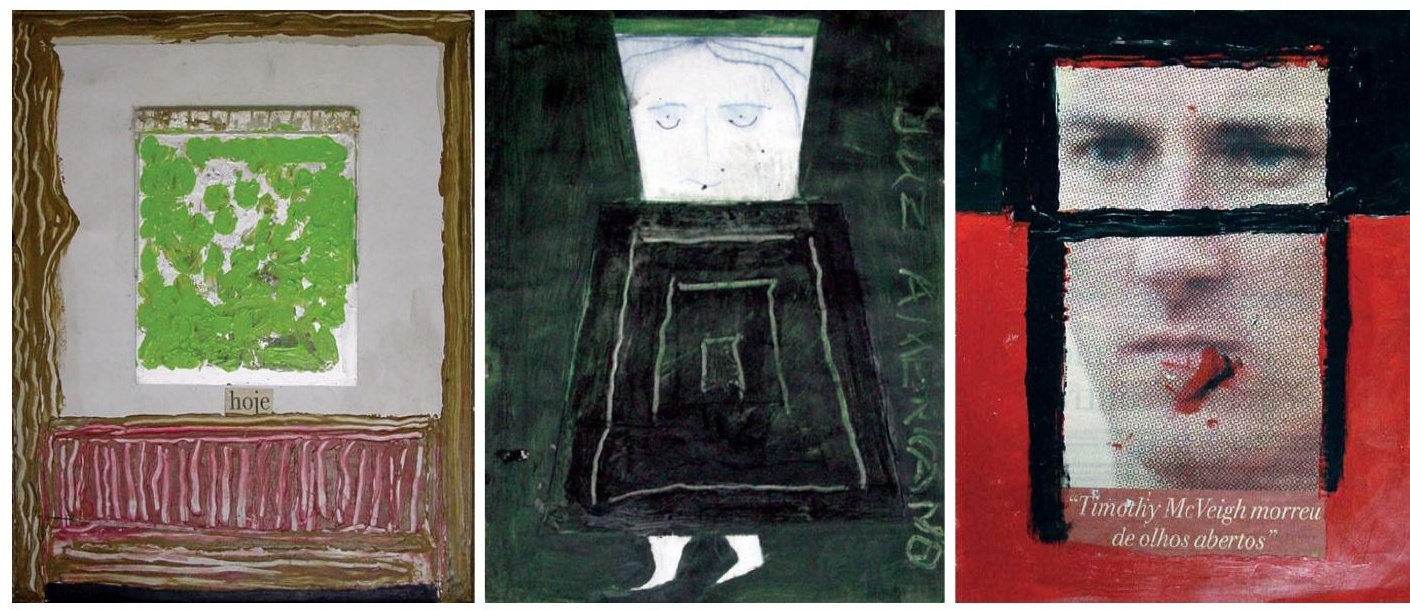

Figura 22. Mário Cesariny, 2006, serigrafia sobre papel fabriano com tampa amovível, $36 \times 26 \mathrm{~cm}$, col. Galeria Perve.

Figura 23. Mário Cesariny, 2006, serigrafia sobre papel fabriano, $36 \times 26 \mathrm{~cm}$, col. Galeria Perve

Figura 24. Mário Cesariny, 2006, serigrafia sobre papel fabriano, $36 \times 26 \mathrm{~cm}$, col. Galeria Perve

Ao levantar a estrutura colocada no centro do plano, o observador confronta a imagem de um grande plano de Thi- 
mothy McVeigh, recolhida da imprensa, e a frase que anuncia a morte do condenado: "hoje Thimothy McVeigh morreu". A frase colocada na continuidade da imagem posiciona o observador perante um acontecimento verídico, contextualizado no espaço e no tempo.

No momento seguinte (Figura 23), Cesariny recupera o tempo cronológico que antecede a execução para representar o julgamento de Thimothy McVeigh. O retrato do condenado, confinado pelos limites pictóricos e por uma sucessão de linhas concêntricas, emerge numa composição onde a ausência de variações cromáticas reforça o caráter implacável e sombrio da justiça. Na lateral direita acrescenta as palavras "JUS AMERICANO", numa alusão à justiça americana. Mário Cesariny aproxima a representação do condenado à imagem da "menina poesia" ou "menina sol", a característica figura de corpo triangular, recorrente na obra plástica do autor. Essa representação, que se mantém quase inalterável ao longo da sua obra, torna-se numa imagem identificativa do autor.

Ao identificar a imagem do condenado com a representação da "menina poesia" ou "menina Sol", assumida como metáfora da identidade poética do autor, Cesariny aproxima, por um lado, a imagem de Thimothy McVeigh à do poeta subversivo e interventor, impulsionador da ação e da transformação, e por outro, identifica a sua própria imagem, enquanto poeta, à do condenado inconformado, que assume uma posição de rutura com a sociedade.

Cesariny enquadra a atitude do condenado Timothy McVeigh no contexto do pensamento poético e do Abjeccionismo. A posição abjecionista, segundo Pedro Oom, um dos seus principais teorizadores, baseia-se na "resposta que cada um dará à pergunta: "que pode fazer um homem desesperado quando o ar é um vómito e nós seres abjectos?" (CESARINY, 1997, p. 292). Perante o desespero "o Poeta só tem como alternativa a angústia ou a abjecção" (CESARINY, 1997, p. 292). À semelhança do poeta abjeccionista, capaz de lutar com todas as suas forças contra aquilo que o oprime, Timothy McVeigh é alguém desesperado, movido por ideias e convicções muito fortes, em completa rutura com o estado americano. Os desenhos seguintes representam a execução do condenado, baseado nas notícias dos jornais da época que descrevem com detalhe a execução de McVeigh por injeção letal.

Num desenho posterior (Figura 24), Cesariny retrata o condenado morto, centralizado no meio de uma composição bipartida em preto e vermelho que acentua a linha do olhar. A 
imagem de Timothy McVeigh, recortada da imprensa, surge no centro do plano - intervencionada com manchas, parcialmente colorida na zona dos olhos e delimitada pela gestualidade do contorno que reforça o olhar do condenado. Embaixo, Cesariny acrescenta um recorte de jornal com a frase, amplamente difundida nos meios de comunicação de todo o mundo: "Thimothy McVeigh morreu de olhos abertos", baseada nos relatos das testemunhas. Os jornalistas que acompanharam a execução descreveram que McVeigh estabeleceu contacto visual com todas as testemunhas, inclusive os parentes das vítimas, manteve-se em silêncio e morreu de olhos abertos, sem mostrar qualquer arrependimento. A frase "morreu de olhos abertos", tem implícita a ideia de que Timothy McVeigh morreu consciente dos seus atos, convicto dos seus ideais. Na argumentação final Cesariny faz o elogio fúnebre do condenado, recorrendo à palavra dos poetas William Ernest Henley, Oscar Wilde e Teixeira de Pascoais.

Assim, a primeira composição (Figura 25) apresenta a "ultima mensagem do condenado", uma cópia do poema Invictus de William Ernest Henley (1849-1903), apresentado por McVeigh como a sua última declaração, quando foi intimado a pronunciar-se. A cópia do poema, colocada no centro do plano, surge intervencionada com manchas e pingos de tinta, posicionada sobre fundo negro, ladeada por ramificações vegetais. O conhecido poema Invictus, que inspirou múltiplas personalidades como Winston Churchill, Nelson Mandela ou Martin Luther King, exalta a liberdade de pensamento. Mesmo perante às maiores dificuldades e obstáculos que a vida coloca, o indivíduo nunca será derrotado, caso ele se mantiver fiel àquilo que dita a sua consciência.

No mesmo sentido, McVeigh, ao escolher o poema Invictus como a sua última declaração, pretendeu transmitir a ideia de que morreu a defender aquilo que acreditava verdadeiramente e, nesse sentido, sairá sempre vitorioso, pois agiu de acordo com a sua consciência, tal como refere o poema: "Não importa quão estreito é o portão/ Quantos castigos são no pergaminho/ Sou o senhor do meu próprio destino/ Sou o capitão da minha alma" (MASINI, 2000).

Na composição seguinte (Figura 26), o contorno do rosto do condenado surge em uma página branca intervencionada com manchas e pingos de tinta, delimitado por uma moldura. Embaixo, Cesariny recupera as últimas palavras do poema $\mathrm{Ba}$ lada do Cárcere de Reading de Oscar Wilde: "No entanto, ouvi: cada um mata o que adora/ o cobarde fere com um beijo/ o 
põe à forma (Figura 27). O poema Verbo Escuro, de onde são retiradas as palavras, exalta o pensamento divergente de todos aqueles que ousam afrontar as leis e os costumes instituídos, revindicando uma forma de pensar que recupera a originalidade, liberdade e pureza da infância: "[...] os que saem para a rua sem chapéu por divino esquecimento! e os que vão a falar sós pelos caminhos...e os que olham a lua, latindo intimamente [...] e os que não se conformam, os que não seguem a lei nem o costume - todas as criaturas onde o anjo da infância sobrevive" (PASCOAIS, 1999, p. 32 ).

A escolha do poema reforça a argumentação desenvolvida ao longo de todo o livro. Tal como o poeta surrealista inconformado e interventivo, agente da ação e da transformação com pretensões de mudar o mundo, também McVeigh é alguém que ousou pensar de forma diferente, afrontando os poderes instituídos, na perspectiva de construir algo novo. Mais do que uma declaração contra pena de morte, o livro assume a defesa do condenado Thimothy McVeigh, numa perspectiva que enquadra a sua atitude no contexto do pensamento surrealista e nos propósitos do Abjeccionismo.

A obra de Cesariny, entendida como projeto abrangente em que convergem o literário, o poético e o plástico, mais do que pretensões literárias ou artísticas, constitui-se como objeto interventivo, com potencial poético, capaz de suscitar nos outros uma consciência potenciadora de uma outra forma de pensar e de agir. Apoiado nos fundamentos do Surrealismo e do Neossurrealismo, empreendeu um projeto global de grande coerência que ultrapassa as fronteiras entre discursos e linguagens artísticas, para expressar de forma inquestionável a convicção na transformação poética do homem.

O estudo das diferentes práticas artísticas que articulam a palavra e a imagem evidenciou a constituição de percursos temáticos, figurativos e ideológicos que derivam de relações intertextuais e interdiscursivas com a própria obra e de outros autores e que põem a descoberto o propósito de afirmação do pensamento poético como o grande impulsionador da transformação do indivíduo e da sociedade.

\section{NOTAS}

${ }^{1}$ A intertextualidade "é um processo de incorporação de um texto num outro, seja para reproduzir o sentido incorporado, seja para transformá-lo." (FIORIN, 2006, p. 30).

${ }^{2}$ É o processo em que incorporam percursos temáticos e/ou percursos figurativos, temas e/ou figuras de um discurso num outro. 
3 “Eu acharei o segredo das grandes comunicações e das grandes combustões. Eu direi tempestade. Eu direi rio. Eu direi furacão. Eu direi folha. Eu direi árvore".

${ }^{4}$ Ver Perfecto Cuadrado (2004, p. 225-226).

5 Editado pela Perve Global - Ltda, com tiragem de 340 exemplares, numerados e assinados pelo autor na contracapa. Impresso totalmente em serigrafia é composto por 16 páginas. Foi lançado no contexto da exposição "Cesariny, Cruzeiro Seixas, Fernando José Francisco e o Passeio do Cadáver Esquisito" (Perve Galeria - 2 Nov. a 22 Dez. 2006).

${ }^{6}$ O' Neill, Alexandre. A Ampola miraculosa. Lisboa: Editora Confluências, 1949. (Col. Cadernos Surrealistas).

\section{Referências}

ADAMOWICS, Elza. Surrealist Collage in Text and Image. Dissecting the exquisite corpse. Cambridge: Cambridge University Press, 1998.

ÁVILA, Maria Jesús; Cuadrado, Perfecto E. Surrealismo em Portugal 1934-1952. Lisboa: Instituto Português de Museus e Junta da Extremadura, 2001.

BRETON, André. Manifesto do Surrealismo. In: Manifestos do Surrealismo. Tradução Pedro Tamen. Lisboa: Edições Salamandra, 1993. p. 13-53.

CESARINY, Mário. A Intervenção Surrealista. Lisboa: Assírio \& Alvim, 1997. . Pena Capital. 3. ed. Lisboa: Assírio \& Alvim, 2005. - Timothy McVeigh - O condenado à morte. Lisboa: Perve Global, 2006.

CUADRADO, Perfecto E. A única Real Tradição Viva. Lisboa: Assírio e Alvim, 1998. . Palavra/Imagem: Confluências. In: PINHARANDA, João Lima; CUADRADO, Perfecto E.. Mário Cesariny. Lisboa: Assírio e Alvim, 2004. p. 217-226.

FIORIN, José Luiz. Intertextualidade e interdiscursividade. In: BRAIT, Beth. Bakhtin: outros conceitos-chave. São Paulo: Contexto, 2006.

GUERREIRO, Manuel. Joan Brossa o la revuelta poética. Barcelona: Generalitat de Catalunya/Departament de Cultura Joan Miró, 2001.

LISBOA, António Maria. Poesia. Lisboa: Assírio \& Alvim, 1995. (Texto estabelecido por Mário Cesariny de Vasconcelos).

MASINI, Andre C. Pequena coletânea de Poesia de língua inglesa. Paraná: Edição do autor, 2000.

PASCOAIS, Teixeira de. Senhora da Noite. Verbo Escuro. Lisboa: Assírio e Alvim, 1999. 
PINHARANDA, João Lima. Quando o pintor é um caso à parte ou as velhas ainda lá estavam. In: PINHARANDA, J.; CUADRADO, Perfecto (Org.). Mário Cesariny. Lisboa: Assírio e Alvim, 2004. p. 11-32.

SANTAELLA, Lucia; NÖTH, Winfried. Imagem, Cognição, Semiótica, Mídia. São Paulo: Editora Iluminuras Ltda, 2008.

WILDE, Oscar. Balada do Cárcere de Reading. São Paulo: Editora Nova Alexandria, 2004. 
Recebido em: 19/04/2017

Aprovado em: 14/11/2017

MICHELE COUTINHO ROCHA

micheleroc@hotmail.com

Faculdade de Belas Artes da Universidade de Lisboa, Portugal. Investigadora de Pós-Doutoramento em Ciências da Arte na Faculdade de Belas Artes da Universidade de Lisboa. 